Arab World English Journal (AWEJ) Volume 12. Number 4. December 2021

DOI: https://dx.doi.org/10.24093/awej/vol12no4.33

Pp. 503-520

\title{
ESL Students' Readiness for Self-Directed Learning in Improving English Writing Skills
}

\author{
Nor Hafizah Adnan \\ Faculty of Education, Universiti Kebangsaan Malaysia \\ Bangi, Selangor, Malaysia \\ *Corresponding Author: norhafizah@ukm.edu.my \\ Siti Shakirah Sayadi \\ Faculty of Education, Universiti Kebangsaan Malaysia \\ Bangi, Selangor, Malaysia \\ sitishakirah.sayadi@gmail.com
}

Received:10/3/2021

Accepted:11/21/2021

Published:12/17/2021

\begin{abstract}
Self-directed learning among students, particularly at the upper secondary level, is still underexplored in Malaysia. Further understanding of ESL students' readiness for self-directed learning in improving English writing skills is crucial to exploit the advantages of this learning method for their benefit. Thus, this study aimed to examine the levels of self-directedness among secondary school students and their readiness to apply self-directed learning in improving English writing skills through a survey design. A total of 50 ESL students in a secondary school responded to two sets of questionnaires that measured different variables in this research. The first questionnaire included a self-rating scale of self-directed learning, which consisted of awareness, learning strategies, learning activities, evaluation, and interpersonal skills. The second questionnaire contained questions about students' readiness for self-directed learning in improving English writing skills. Sampling was done randomly without considering students' academic level of English. The findings found that most students possessed a medium level of self-directedness with not much difference with the high-level ones. The study then revealed a positive relationship between students' level of self-directedness and students' readiness to incorporate self-directed learning in English writing skills. For instance, students with a high level of self-directedness scored higher in students' readiness for self-directed learning in improving English writing skills than those with a low level of self-directedness. Future studies should consider self-directed learning strategies to promote lifelong effects of positive attributes towards learning experiences, such as discipline, attention, responsible, and creativity in planning learning objectives.
\end{abstract}

Keywords: ESL student, English writing skills, level of directedness, self-directed learning, students' readiness

Cite as: Adnan, N.H., \& Sayadi, S. S. (2021). ESL Students' Readiness for Self-Directed Learning in Improving English Writing Skills. Arab World English Journal, 12 (4) 503-520.

DOI: https://dx.doi.org/10.24093/awej/vol12no4.33 


\section{Introduction}

Self-directed learning is an inclination to pursue learning activities in which the individual takes ownership and personal responsibility for their learning experiences. In selfdirected learning, learners are responsible for formulating and conducting their initiative and effort without teachers, parents, and friends (Knowles, 1975). However, an advisor can play a part in this learning as a gatekeeper to the students' learning practice. Self-regulated learning is another similar term to self-directed learning. Self-regulated learning is a dynamic and positive process that allows learners to create their learning objectives and then supervise, modulate, and ensure their cognition, motivation, and behavior according to the contextual features (Bandura, 2001; Pintrich \& De Groot, 1990; Schunk, 2005; Zimmerman, 2002).

In the 21 st century, self-directed learning is a method to engage learners in learning activities independently at their own pace and accountability. The learners hold an autonomous role in SDL, unlike in traditional learning settings whereby the teachers play the autocratic style in a classroom (Lounsbury et al., 2009). On the other hand, writing skills are one of the crucial skills in English. Writing skills are often tested and serve as part of the indicators in examination and assessment. Writing skills are also an essential element of communication, either for personal use, such as writing on social media, academic purpose, or professional means.

\section{Background of the Study}

This study recognized learners' dependency on teacher instruction for writing tasks as the main element, showing a lack of own initiative and practice in English writing skills among learners. The lack of promotion and exposure of self-directed learning methods among secondary school students, also the active roles of teachers, parents, and peers in encouraging learners' autonomous role in learning, remain underexplored in Malaysia. In response to the demand for a 21st-century education, teaching strategies that centered on students have been endorsed in many developed countries, highlighting the capabilities and attitudes of beyond content knowledge, namely: higher-order thinking, problem-solving skills, self-directed learning, teamwork, communication skills, planning and organizing skills, and self-management skills (Kaufman, 2013).

Malaysia aspires to become a developed nation (Bakar et al., 2020), but the country is still far from promoting self-directed learning and very dependent on rote learning in teachercentered classes (Asfar \& Zainuddin, 2015; Ibrahim et al., 2017; Peen \& Arshad, 2017). The traditional methods used in schools at the recent time do not encourage students to become active and independent learners. Instead, it will produce a passive and dependent learner, implying that students should depend on the teachers for information, drill, and practice activities, as well as learn only for examination purposes (Blachowicz \& Ogle, 2017). Some improvements are necessary to transform passive and traditional learning activities into an active and engaging learning experience to produce holistic students, not only in language learning and acquisition (Ibrahim \& Adnan, 2020). Thus, providing ample opportunities and a conducive learning environment in Malaysia secondary school for students to take autonomous roles in their learning could be done by having collaboration or individual works by themselves, with some guidelines and instructions provided by the instructor or teachers. 


\section{Significance of the Study}

The purpose of this study was to provide additional affirmation and support for the development of self-directed learning strategies to be widely implemented in educational institutions, particularly in secondary school. Boyer et al. (2017) endorsed self-directed learning as an alternative way of the learning experience and in the language context, to enhance language skills and acquisition of an individual, thus nurturing an autonomous method of learning in the 4th Industrial Revolution that works closely with the education field. The self-rating scale of self-directed learning developed by Williamson (2007) served as a guideline and instrument for this study, promoting self-directed learning awareness among teachers and learners on the possibilities and direction of self-directed learning. In the second questionnaire, English writing skills were selected as the element for improvement to ensure the result was more concise, visible, and specific.

In anticipation of Malaysia Education Blueprint 2013-2025 as the guideline in Malaysia Educational transformation, self-directed learning is a fundamental element in developing a highquality education system as practiced and promoted by a developed nation, such as Finland that holds the best education system in the world. Self-directed learning allows students to explore knowledge and learning experiences beyond examination purposes, empowering their leadership skills, bilingual proficiency, and cognitive skills, namely: critical thinking, reasoning, creative thinking, and innovation for becoming a competitive global resident (Knowles, 1975). Therefore, this research was fundamental to the educational system and worthy to be explored further.

Results from this study provided a better understanding of the levels of self-directedness among secondary school students and their readiness for self-directed learning in improving English writing skills. Also, this study could provide more insights on how secondary school students can manipulate self-directed learning strategies in improving their English writing skill performance. As the students hold an autonomous role in deciding their own pace and selfdirected learning strategies suitable for them, students can learn how to be responsible for their learning process. Nevertheless, teachers can provide students with lists of effective self-directed learning strategies for assisting them.

\section{Literature Review}

\section{Autonomy and Language Learning}

According to Littlewood (1996), an individual with autonomy is independent in making and performing the options that control their activities, dependent on two focal elements, ability and willingness. In this context, autonomy may imply our capability of thinking and acting independently to ensue in numerous situations, especially one that focuses on learning. Benson (2011) mentioned learner autonomy requires the learners to have more control of their learning process. This definition is also often associated in the recent work with the philosophical idea of personal autonomy, which involves those who strive for greater control over their lives.

However, it is likely to fuse autonomy with almost similar concepts. Benson (2007) stated most people agreed that either autonomy or autonomous learning is not equivalent to 'selfinstruction,' 'self-access,' 'self-study,' 'self-education,' 'out-of-class learning,' or 'distance learning.' These terms explain various methods and levels of learning by oneself, which autonomy refers to skills and attitudes, or in other words, the ability to control their acquisition of knowledge or skills. The idea is that learning itself is not similar to being able to learn alone. 
Other than that, to be autonomous learners, students need to acquire ways to control or ownership of their learning.

\section{Autonomy Elements}

Littlewood (1996) also added two focal elements in learning autonomy, which are ability and willingness. These two components are interchangeable in some situations, given that an individual might be able to induce their option independently with the absence of willingness, perhaps due to internal perception. The same goes for an individual who is willing to conduct an activity but cannot do so. Ability cares about acquiring knowledge on the alternate options and required skills in performing fitting choices. Willingness then is concerned with both motivation and confidence to be responsible for the option taken. Therefore, all these four fundamental elements must be present collectively for an individual to be autonomous effectively (Littlewood, 1996).

\section{Autonomy Stages}

Littlewood (1996) mentioned that autonomy operates on a hierarchy of various behavior levels whereby an independent individual renders their own decision. The low-level options regulate a particular process and encourage the execution of the activity situated at the bottom of the hierarchy. The high-level options manage general activity, whether to execute it, which is placed at the top of the hierarchy various behavior levels. For instance, the progression of growing autonomy in utilizing and acquiring a language is as follows:

- Students can make their grammar and vocabulary choices, which is the first step towards self-consultation, such as controlled role-plays and simple information exchange tasks,

- Students select their meaning and communication strategies to achieve their communication goals,

- Students can decide on goals, meanings, and strategies in greater depth, i.e., creativity, problem solve and talk,

- Students start to choose and form their learning contexts, such as in self-directed learning and project work,

- Students can take decisions in a situation whereby it is the traditional part of the educator, i.e., on materials and learning,

- Students take part in defining the nature and progress of their curriculum,

- Students can use language independently for communication \& learning outside of the classroom in situations of choice.

Nunan (1996) developed a five-level model of the learners' action, including awareness, involvement, intervention, creation, and transcendence. In all of these levels indicated the learners' development activities order in language textbooks. At the awareness level, students will be connected to the pedagogical objectives and learning contents, identifying the strategic implications of pedagogical tasks, ideal styles, or learning strategies. Next, learners would associate the content of classroom learning with the real world. Although the model created by Nunan (1996) persisted in the language learning framework, the three-stage model of Littlewood (1996) comprised dimensions in language acquisition, the approach of learning, and personal development. In a language acquisition setting, autonomy includes the ability to independently work with the language in an actual and impulsive situation (autonomy as a communicator). In 
classroom organization, students must be responsible for their learning (Adnan, 2018) and manage an active and individually relevant strategy (autonomy as a learner). In a wide range of settings, autonomy includes a universal individual with an upper-level goal (autonomy as a person).

\section{Autonomy Framework}

According to Littlewood (1996), three general autonomy domains can be further segregated into particular parts and serve as the foundation of developing realistic tactics:

- Autonomy as a communicator is established by the adeptness in using language in creative ways and also the adeptness in utilizing suitable tactics in imparting meaning in some situations,

- Autonomy as a learner is determined by the aptitude to take part in independent activities, for instance, self-directed learning, and also the aptitude to utilize suitable learning strategies, both inside and outside of the classroom,

- Autonomy as a person is influenced by the foreign language learning perspective, for instance, the aptitude in conveying respective meaning and the aptitude to come up with personal learning perspectives, such as outside classroom interaction.

\section{Distance Learning}

According to Moore and Kearsley (2011), distance learning enables people in geographically remote locations to have widespread access to learning opportunities. The study demonstrated different authors and researchers were using inconsistent definitions of distance education and distance learning over the past two decades. When computers were used for education, distance learning was usually associated with delivering content and instructional material via print and electronic media (Moore \& Kearsley, 2011). Nonetheless, the interchangeableness of distance education and distance learning is very much opposed by King et al. (2001) as both terms are dissimilar. Distance learning is regarded as an ability, while distance education means learning at a distance or more on the activity inside the said ability. Yet, the differences between these terms are bounded by the dissimilarities in time and place (Clark, 2020).

\section{e-Learning}

The foundation of the term e-learning remains ambiguous, though it derived in the 1980s from other online teaching methods within the same timeframe. Some authors defined e-learning explicitly, while others suggested a specific e-learning definition or view in their articles. Some of these definitions materialized through conflicting opinions about other descriptions by comparing defining features with existing terms. Decades ago, Ellis (2004) disagreed with Nichols (2003), who described e-learning as being firmly accessible via technology tools in webbased, web-distributed, or web-capable formats. Ellis (2004) stated that e-learning includes content and instructions delivered through CD-ROMs, the Web, or an Intranet (Benson, 2011; Clark, 2020) and also comprises audio and videotape, satellite transmission, and interactive TV. Tavangarian et al. (2004) and Triacca et al. (2004) considered the technology as a descriptor was inadequate despite having technical characteristics included in its definition. Tavangarian et al. (2004) also incorporated the theoretical model of constructivism as a basis for the term by claiming that e-learning is more than just procedural since it can transform an individual's experience into knowledge through the process of knowledge building. 


\section{Online Learning}

Most authors described online learning as using technologies to access learning experiences (Benson, 2011; Huang, 2002). Other authors described online learning as mere online learning (Oblinger \& Oblinger, 2005), while others referred to the medium of technology or the learning context. Two decades ago, Benson (2011) and Huang (2002) identified online learning as the latest distance learning that enhances the availability of non-traditional and disadvantaged educational openings to learners. Other writers also discussed the accessibility of online learning and its linkage, flexibility, and capability in promoting wide-ranging interactions (Ally, 2004; Oblinger \& Oblinger, 2005). Hiltz and Turoff (2005) did not only evade the connection of online learning to distance learning and conventional delivery systems, but they also claimed online learning is a better version of distance learning. Like other authors, they believe that distance education or learning is related to online learning, but their descriptive narratives are still vague.

"MOOCs and their platforms, such as Coursera, edX and Udacity scale up traditional online courses for multiple learners by providing online video lectures, discussion forums, assessments, peer-evaluations, and exams graded automatically. However, the structure of many of these MOOCs is predominantly a teacher-centred approach. MOOCs differ from face-to-face courses as students can learn at their own pace, independently drive the learning process, and enable them to repeat or skip lessons" (Adnan \& Ritzhaupt, 2018, p. 90).

\section{Attitudes and Motivation in Learning English as Second Language}

According to Spolsky (1969), attitude is an essential key factor contributing to Second Language (L2) learning accomplishment. Moreover, the students' attitudes also determine to which extent the students continue to participate actively in the language learning process $(\mathrm{Wu}$, 2008). Thus, there are two different forms of attitude concerning language learning, namely positive and negative. Many researchers found the benefits of positive behavior whereby L2 positive students have more advantages over negative attitudes (Littlewood, 1996; Spolsky, 1969). Therefore, this statement proved that the attitudes of students correspond positively to their performance in English. This claim was supported by a few opinions on the hindrance of negative attitudes towards L2 by Gardner and Lambert (1972) that contended students with negative attitudes towards L2 are likely unfriendly, ethnocentric, and put less effort in discussing L2. In placing more emphasis, Littlewood (1996) also bore the assumption that these students do not show an attempt to learn.

Although the importance of the English language is generally acknowledged, most Malaysian students show a lack of effort to learn English (Ibrahim \& Adnan, 2020). A case study done by Razali (2017) recognized that the poor performers recognized the importance of English for instrumental purposes and took a positive view of its use, standard, and status but did not demonstrate positive attitudes towards language learning. Furthermore, students spent minimum effort to enhance their proficiency both inside and outside of the classroom.

In L2, motivation is crucial. There are two different types of motivation: namely intrinsic and extrinsic. According to Bandura (1977), intrinsic motivation is an inclusive orientation that denotes the wish of executing action without external incentives or rewards. On the other hand, Hennessey et al. (2015) stated that extrinsic motivation is typically related to the instrumental 
guidance and the intention of learners to achieve an external recompense. Nonetheless, the connection between extrinsic motivation, intrinsic motivation, and performance was frail. Also, both extrinsic motivation and intrinsic motivation do not directly influence students' English language performance. Apart from motivation, students' attitudes have a significant impact on their performance in the language.

Gardner and Lambert (1972) believed that positive and highly motivated students are likely to be more successful than negative and unmotivated ones. To achieve the most effective language experience, both motivation and a positive attitude need to be synchronous. For instance, as a language learner, a student who possesses an encouraging attitude in language learning but less effort to learn cannot be a successful language learner. The same goes for those who have the motivation or desire for learning but are unwilling to learn (Gardner \& Lambert, 1972).

\section{Students and Writing Skills}

According to Ansarimoghaddam and Tan (2014), ESL scholars, educators, and instructors always emphasize that writing is an essential language skill. Flower and Hayes (1980) suggested that writing is a direct speech act of what the author means, their intellectual struggles, and interpretations. Razali (2017) also emphasized writing as an integrative skill, a major, productive, and complex learning process. Thus, writing can be defined as an effective learning process, starting from generating ideas and collecting necessary information until the final text is published. Hyland (2018) mentioned that writing is a way of communicating, confronting, and thinking because the author's thoughts and writing are combined when the author begins to write. In terms of writing attitude, it is related to the students' feelings and beliefs, including their writing abilities and written language tasks.

Razali (2017) examined students' tendencies, beliefs, and myths of their writing practices and recognized that most students viewed writing as a product rather than a process. This statement is nearly unrelated or important to reading, exploring, and reflecting, or discerning new ideas. Students also perceived writing as a product of arbitrary grammar rules instead of a process based on the flow of thoughts and ideas (Ibrahim \& Adnan, 2020). Many researchers carried out empirical studies on student writing (Zheng \& Yu, 2019). Most studies revealed that students focused on how many phrases and pages they wrote instead of discovering new ideas. They did not promote controversial views and arguments but applied these in writing to abstract grammar rules. Conclusively, instead of learning to write creatively, they obeyed particular models of writing. Therefore, it is essential to offer students with abundant opportunities to practice writing.

\section{Error Analysis of the Written English Essays of Secondary School Students in Malaysia}

Darus and Subramaniam (2009) conducted an error analysis on essay samples from 72 ESL students in form four (16 years old) who completed their primary education in public schools. All participants had a similar educational background and went through ten years of primary and secondary education. The researchers identified the most frequent errors in essay samples. Singular/Plural form contributed to the highest errors committed, followed by Verb Tense, Word Choice, Prepositions, Subject-Verb Agreement, and Word Order. Other prominent 
types of errors committed by the participants were Articles Error, Missing Space, Word Form, Spelling, Verb Form, Capitalization, Wrong/Misused Word, Redundancy, and Missing Word.

According to Darus and Subramaniam (2009), there were explanations behind every error done by the participants. For instance, in the Singular/Plural form, some participants failed to understand the rule for the countable plural noun should be applied with suffix 's.' Some participants could not notice of the countable plural noun, but might unsure when the rule should be applied. This is might due to the absence of a plural marker for a noun in the Malay language. While in Verb Tense, the participants failed to apply the correct tense to the verb in a sentence. Some participants may be unaware of the various rules on the application of tenses. The uses of certain suffixes, such as 'ing' and tense forms from the past, showed that participants recognized the rules for different timing and assumed that these verbs must be used in different tense forms and not in a basic form. Some verbs were written using a variety of tenses and not in the fundamental form of the verb.

In Word Choice, the researchers believed that the participants possessed inadequate vocabulary. In the sample essay, a participant used the word 'flour' instead of 'floor' in the sentence, "Not washing and sweeping the flour every day makes the floor dirty." Another participant selected the word 'healthy' instead of 'safe' in a sentence, "The workers should keep the canteen clean and healthy." In another sample, a participant used the word 'staff' instead of 'workers' in a sentence, "This is due to the irresponsible attitude of the canteen staff."

As for prepositions, some participants failed to establish the correct application of prepositions in a sentence. For instance, a participant used the preposition 'at' instead of 'around' in a sentence, "So many dirty plates and glasses can be seen everywhere at the school canteen." While in the sentence, "The food to cater to the students during recess is not enough," the appropriate preposition would be 'for' and not 'to.' Last but not least, in a sentence, "As the secretary at the club I have been assigned to write a report," the participant should apply the preposition 'of.'

Other than that, few participants had difficulties in constructing a simple or complex sentence. The English language possesses a rigid word order, namely as Subject-Verb-Object (SVO). Therefore, a complete sentence must begin with a subject, followed by a verb and an object (if necessary). In English, a complete sentence must comprise a minimum of a subject and a verb. The participants committed a few errors such as missing/wrong object, absence of subject and verb in their sentences. This kind of error produces sentences with vague and incomplete meanings.

In a nutshell, the study indicated that errors committed by the participants were fundamentally grammatical. They also have insufficient vocabularies that may contribute to their incomprehensible sentences at times. Moreover, from the mistakes committed in English sentence structure rules, it is understood that these participants might experience issues regarding standard English grammar rules acquisition so that they can focus on these types of errors.

\section{Self-Directed Learner}

The key features to describe self-directed learners are possessing a high degree of auto 
efficiency, intrinsically motivated, recognizing the needs of their learning, placing objectives based on the analysis, deciding suitable strategies to achieve those objectives, assessing its goal based on internal evidence and external feedback, and ready to address new challenges (Pintrich \& De Groot, 1990; Schunk, 2005). Knowles (1975) suggested self-managed learning is an approach where learners are motivated to undertake personal responsibility and build meaningful learning results in cognitive (self-management) and contextual (self-management) procedures.

The self-direction of the learner focuses on the desire or preference of the learner, or in other words, learning responsibility (Ibrahim et al., 2017). Peen and Arshad (2017) proposed factors that influence self-directed learning: self-effectiveness, conscientiousness, epistemological beliefs, and belief in internal control. A trained local facilitator may interview people with low self-directed learning indicator results to see if they need help with low selfefficacy, self-motivation, goals, and organization or evaluate their control locus. On-site educators and facilitators will need some training on how these students can be supported and assisted in increasing their self-efficiency, internal control, and autonomy. The aim of governing students' self-direction was to provide appropriate support, so they can start taking responsibility for their learning and completing the online courses and not impede access to online learning opportunities.

\section{Self-Directed Learning in Malaysia Education National Blueprint 2013-2025}

As time fast forward with the rapid increase of technology, the necessity of building firstclass human capital in fulfilling the needs of today's world is vital at its best. Therefore, a set of prominent and essential skills known as 21 st Century Skills are the most sought-after skills that every individual should possess, regardless of professional, academic, or personal field. In education, children require skills, such as 3Rs, namely Reading, wRiting, and aRithmetic, to cope with changing demands as they grow up. Many countries in the world realize the importance of including 21st Century Skills in their curriculum but 21st Century Skill is still underexplored. Nevertheless, Malaysia's Ministry of Education believes that being assertive, self-directed learner, an active provider, and aware civilian as the outcomes guaranteed from a person with well-equipped 21st-century skills (Malaysia Education National Blueprint, 2013).

Ministry of Education Malaysia initiated the using the ICT model for providing efficient English instruction to students via the implementation of the 1BestariNet system. This personalized learning was accustomed to individual needs and highly accessible (Malaysia Education National Blueprint, 2013). Self-directed learning is not only for students but also for improving teachers' proficiency in English, especially for those who possess poor English language proficiency and are incompetent. Teachers should attend an English training course for four hours a week for 44 weeks without affecting school hours or teaching and learning sessions. Teachers also need to undergo an intensive English training course, an eight-week immersion program, and eight-week self-learning courses. The self-learning course comes in modules and is a computer-based program where teachers need to conduct self-directed learning for 30 hours per week.

\section{Methodology}

This study employed a quantitative research method that involved two sets of questionnaires. The first questionnaire aimed to examine students' level of self-directedness, 
while the second questionnaire sought to investigate students' readiness for SDL in improving English writing skills.

\section{Participants}

The questionnaires were given to 50 randomly selected Form 4 students aged 16 years old. Form 4 students were likely to have acquired better and richer English language experience and motivation than the younger ones. The age and the maturity of the participants played crucial roles in this study and its finding. Wan et al. (2014) selected a final year student cohort in their research as they believed the participants were likely to have more linguistic competence and motivation than younger students. Knowles (1975) suggested that as individuals grow, they possess an accumulated reservoir of experiences that can use them as a learning resource.

\section{Instrument}

There were two sets of instruments used to fulfill the research objectives. The first questionnaire was Williamson's (2007) self-rating scale of self-directed learning, which contained 60 items with 12 questions from five different sections, namely awareness, learning strategies, learning activities, evaluation, and interpersonal skills. The response keys are as follows: 5=Always, 4=Often, 3=Sometimes, 2=Seldom, and $1=$ Never. There were three categories of the results: low, medium, and high levels of self-directedness.

The second questionnaire comprised ten questions (Yes/No) about students' readiness for self-directed learning in improving English writing skills. These inventories helped understand students' willingness to incorporate self-directed learning strategies as one of the efforts to enhance their English writing skills. Both questionnaires include demographic questions for extracting information on respondents' gender, age, and race for reporting purposes.

\section{Data Collection}

The questionnaires took about 10 minutes to complete via an online survey tool. The online tool allowed participants to enter their inputs directly into the system. Also, an online survey tool enabled the researchers to collect and generate data swiftly, saving time and costeffectiveness. The researchers welcomed any further questions by the participants via WhatsApp and Telegram. The correlation analysis was conducted by using the information obtained from the survey and the self-directed learning portfolio to answer the research questions as follows: Q1. What are the levels of self-directedness of form four students?

Q2: Is there any relationship between students' level of self-directness in the learning process and their readiness for self-directed learning in improving English writing skills?

The null hypothesis colligated with the above questions as follows:

H02 - There is no significant relationship between students' level of self-directness in the learning process with their readiness for self-directed learning in improving English writing skills?

\section{Data Analysis}

All data obtained from the survey were first analyzed using a spreadsheet to gain the total marks from both questionnaires, respectively. For the first questionnaire, all responses were summed up and matched to their levels of self-directedness, such as low, medium, and high. As 
for the second questionnaire, each 'Yes' response carried 10\% of the scores, whereas a 'No' response carried $0 \%$. The total scores indicated the score of readiness for students in using selfdirected learning for improving English writing skills. The maximum score would be $100 \%$. The mean, median, and mode for participants with medium and high levels of self-directedness were further analyzed using IBM-SPSS 2016 statistical software. The correlation between students' level of self-directedness and students' readiness for levels of self-directedness in improving English writing skills was analyzed using Pearson Correlation.

\section{Results}

A total of 50 students (form 4) from a secondary school in Semenyih, Selangor, Malaysia, participated in this research. The majority of the respondents were female students, which made up $68 \%$ of the total respondents, followed by male students by $32 \%$. Most of the respondents were Malay with 56\%, followed by Chinese with $32 \%$, Indian with $10 \%$, and Sikh with $2 \%$.

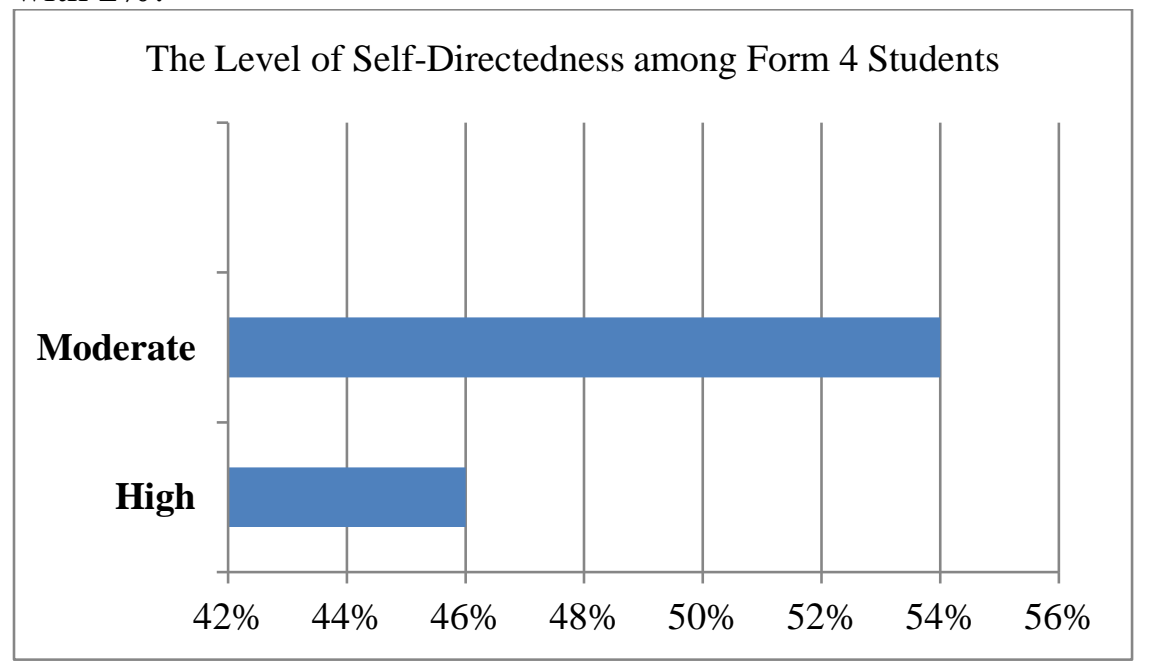

Figure 1. The level of self-directedness

This study adopted a questionnaire from Williamson's Self-Rating Scale of Self-Directed Learning (2007) for the first part of the survey. $46 \%$ of the participants scored a high level of self-directedness, with 54\% scoring at a moderate level of self-directedness. $0 \%$ recorded for a low level of self-directedness. This result showed that the participants were self-directed learners that require more exposure and guidance on self-directed learning strategies.

Williamson (2007) stated that those with a moderate level of self-directedness are already halfway from becoming self-directed learners. However, they need to recognize and evaluate a few areas for improvement, and some strategies might need to be adopted together with a teacher's guidance if necessary. Those with a high level of self-directedness may need to maintain their progress by finding effective and suitable methods to strengthen their self-directed learning. Williamson (2007) also added that no matter which level of self-directedness scores, they still need to pay more attention to the items scored 1-Never and 2-Seldom to improve one's self-directed learning. 
The second questionnaire consisted of 10 Yes/No questions regarding students' readiness for self-directed learning in improving English writing skills. All items received a higher percentage of Yes response and a relatively good mean score. This result showed that most participants were willing and ready to use self-directed learning in improving their English writing skills.

Table 1. Students' readiness for self-directed learning in improving English writing skills

\begin{tabular}{|c|c|c|c|c|}
\hline Question & Yes & No & Mean & $\begin{array}{l}\text { Std } \\
\text { Deviation }\end{array}$ \\
\hline $\begin{array}{l}\text { 1.Are you familiar with Self-Directed Learning } \\
\text { (SDL) strategies? }\end{array}$ & $74 \%$ & $26 \%$ & 1.26 & .443 \\
\hline $\begin{array}{l}\text { 2.Are you interested to learn on how to use } \\
\text { Self-Directed Learning in improving your } \\
\text { English writing skills? }\end{array}$ & $82 \%$ & $18 \%$ & 1.18 & .388 \\
\hline $\begin{array}{l}\text { 3.Are you ready to learn on how to use Self- } \\
\text { Directed Learning in improving your English } \\
\text { writing skills? }\end{array}$ & $80 \%$ & $20 \%$ & 1.20 & .404 \\
\hline $\begin{array}{l}\text { 4.Are you ready to practice Self-Directed } \\
\text { Learning strategies in improving your English } \\
\text { writing skills once you have learnt about them? }\end{array}$ & $80 \%$ & $20 \%$ & 1.20 & .404 \\
\hline $\begin{array}{l}\text { 5.Are you willing to go for a workshop on how } \\
\text { to use Self-Directed Learning (SDL) strategies } \\
\text { in improving English writing skills if any? }\end{array}$ & $66 \%$ & $34 \%$ & 1.34 & .479 \\
\hline $\begin{array}{l}\text { 6.Are you going to promote Self-Directed } \\
\text { Learning strategies to your family and friends if } \\
\text { it is proven to improve your English writing } \\
\text { skills? }\end{array}$ & $82 \%$ & $18 \%$ & 1.18 & .388 \\
\hline $\begin{array}{l}\text { 7.At this point, do you have a positive } \\
\text { impression towards Self-Directed Learning } \\
\text { strategies in improving your English writing } \\
\text { skills }\end{array}$ & $84 \%$ & $16 \%$ & 1.16 & .370 \\
\hline $\begin{array}{l}\text { 8.Do you expect to experience positive English } \\
\text { writing skill learning process with Self- } \\
\text { Directed Learning strategies? }\end{array}$ & $80 \%$ & $20 \%$ & 1.20 & .404 \\
\hline $\begin{array}{l}\text { 9.Do you prefer to have a teacher as your } \\
\text { facilitator to facilitate your Self-Directed } \\
\text { Learning in English writing skills }\end{array}$ & $84 \%$ & $16 \%$ & 1.16 & .370 \\
\hline $\begin{array}{l}\text { 10.Are you hoping for a better English writing } \\
\text { skills after practicing Self-Directed Learning } \\
\text { strategies after certain period? }\end{array}$ & $80 \%$ & $20 \%$ & 1.20 & .404 \\
\hline
\end{tabular}

Focusing on two items with the highest mean scores, item 1 with a mean score of 1.26: Are you familiar with Self-Directed Learning strategies? 74\% of the participants were familiar with self-directed learning concepts. Another $26 \%$ of the participants were not familiar with these learning strategies. This information was significant for educators, allowing them to plan introductory courses for self-directed learning since they can manipulate the concepts for improving student learning experience and skills, such as English writing skills. The strategies are very crucial to encourage students' interest in using self-directed learning.

Next item with the highest mean score of 1.34, item 5: Are you willing to go for a workshop on how to use Self-Directed Learning strategies in improving English writing skills if 
any? This item scored the highest No responses than others since this might be because the students feel reluctant to join other programs that are not compulsory and contributes to their attendance.

Table 2. The relationship between the level of self-directedness and students' readiness for selfdirected learning in improving English writing skills

Statistics

\begin{tabular}{|c|c|c|c|c|}
\hline \multicolumn{3}{|c|}{ Level_of_Self Directedness } & Readiness_Score & \\
\hline \multirow[t]{5}{*}{ Moderate } & $\mathrm{N}$ & Valid & 27 & \\
\hline & & Missing & 0 & \\
\hline & & & 73.70 & \\
\hline & & & 80.00 & \\
\hline & & & 90 & \\
\hline \multirow[t]{5}{*}{ High } & $\mathrm{N}$ & Valid & 23 & \\
\hline & & Missing & 0 & \\
\hline & & & 85.22 & \\
\hline & & & $\begin{array}{l}90.00 \\
100\end{array}$ & \\
\hline & & & & 100 \\
\hline
\end{tabular}

Table 2 showed students with a high level of self-directedness displayed higher readiness scores than those with a moderate level of self-directedness. Additionally, there was a slight difference in the mean scores of the readiness between the two groups, High, with 85.22\%, and Moderate, with $73.70 \%$. Moreover, the minimum and maximum scores for high-level selfdirectedness were higher than the moderate level as it scored min 50\%; max $100 \%$ compared to the moderate ones with $\min 30 \%$; $\max 90 \%$.

Table 3. Correlation between level of self-directedness and readiness score

\section{Correlations}

\begin{tabular}{|c|c|c|c|}
\hline & & $\begin{array}{l}\text { Level of Self } \\
\text { Directedness }\end{array}$ & Readiness_Score \\
\hline $\begin{array}{l}\text { Level of Self } \\
\text { Directedness }\end{array}$ & $\begin{array}{l}\text { Pearson } \\
\text { Correlation } \\
\text { Sig. (2-tailed) } \\
\text { N }\end{array}$ & $\begin{array}{r}1 \\
50\end{array}$ & $\begin{array}{l}.296^{*} \\
.037 \\
50\end{array}$ \\
\hline Readiness Score & $\begin{array}{l}\text { Pearson } \\
\text { Correlation } \\
\text { Sig. (2-tailed) } \\
\text { N }\end{array}$ & $\begin{array}{r}.296^{*} \\
.037 \\
50\end{array}$ & $\begin{array}{l}1 \\
50\end{array}$ \\
\hline
\end{tabular}

*. Correlation is significant at the 0.05 level (2-tailed). 
Table 3 showed a weak positive linear relationship and significance between the level of self-directedness in learning and students' readiness for self-directed learning in improving English writing skills $[\mathrm{r}=.296, \mathrm{n}=50, \mathrm{p}<0.05]$. Thus, there was a possibility that the higher the level that one's scored in self-directedness in learning, the higher the readiness score would be.

\section{Discussion}

Findings revealed that secondary school students possessed different self-directedness levels. Most students were not aware of self-directedness and were not exposed explicitly to how to conduct self-directed learning systematically. With the increasing access to technological tools and online educational materials at their fingertips, students can find information and do not need to wait for materials and further instruction from a teacher in a classroom. For instance, students may browse the internet to search for a sample of formal letter essays before examination without being instructed by the teacher. The motivations and attitudes of students in learning English as a second language can be nurtured through the introduction of self-directed learning strategies. They can learn how to adapt strategies such as flexibility, space, time, and pace to master English language skills, including reading skills, writing skills, listening skills, and speaking skills to acquire particular language components as grammar rules and vocabular.

These findings could be linked to the two focal elements in learning autonomy as suggested by Littlewood (1996), namely, ability and willingness. Ability cares about acquiring knowledge on the alternate options and required skills in performing fitting choices. Willingness is concerned with the acquisition of motivation and confidence to be responsible for the option taken. Thus, all these elements must be present collectively for an individual to be autonomous effectively. Since none of the participants scored a low level of self-directedness, this was apparent evidence that secondary school students have the self-directedness drive embedded in themselves. However, it requires further action to ensure that self-directed learning happens consistently and systematically.

\section{Implications to the Students}

By acknowledging the level of self-directedness, students can address their strengths, weaknesses, and preference in learning. All items in the first questionnaire enabled students to gain a better understanding of conducting self-directed learning. Self-directed learning also allows students to take ownership of their learning process. They might experience fear and anxiety of having to direct their learning at the beginning of the process. Spolsky (1969) suggested that attitude is an essential key factor contributing to L2 learning accomplishment, while $\mathrm{Wu}$ (2008) believed that students' attitudes determine to which extent the students continue to participate actively in the language learning process.

Not to mention, some might feel inadequate without formal instruction from an expert like a teacher. Therefore, the systematic introduction of self-directed learning to students at a young age would enable them to familiarize themselves with the necessary steps for a successful self-directed learning experience and strategies over time. According to Ibrahim et al. (2017), students experienced a positive transformation from feeling uncertain to being confident and skillful in self-direction accompanied by the teacher's support towards the end of the journey. 


\section{Implications to the Educator and Education Policy Makers}

By getting information on students' level of self-directedness in learning, educators and education policymakers can gain more insights on how to develop instructional materials accordingly (Adnan \& Ritzhaupt, 2018). Thus, educators and education policymakers can accommodate students' needs and support by formulating their mindful endeavors to improve themselves. Other than that, the educators can recognize the students' areas of deficits in learning and offer assistance according to their independence or dependence on learning by considering students' necessity (Williamson, 2007).

The positive relationship between the levels of self-directedness and students' readiness score for self-directed learning in improving English writing skills will allow the education policymakers to address critical components in constructing the scheme of work for English subjects, particularly in writing skills. Therefore, the educators are responsible for building students' full aptitude for successful self-directed learning by supporting each other via congruent teamwork.

Moreover, the items listed in the second questionnaire will allow the educator to plan suitable ways to nurture students' interest in developing their self-directed learning potentials. For instance, in item 5, students are willing to attend a workshop on self-directed learning to improve their self-directed learning skills and strategies, although this item recorded the highest 'No' responses compared to others. Nevertheless, the educators could arrange a self-directed learning workshop for the students based on the responses received in the second questionnaire. Also, item 9 enquired whether students prefer to have a teacher as a facilitator in guiding their self-directed learning, and most of them agreed with the statement. Therefore, educators can act as facilitators to assist a group of students in a self-directed learning group.

\section{Conclusion}

In-depth and further understanding of students' level of self-directedness in learning will provide massive advantages for educators and students (Adnan et al., 2020; Hashim et al., 2020). Congruent teamwork between teachers and students will ensure a successful self-directed learning experience in improving students' English writing skills. Self-directed learning strategies are not only limited to a certain level of learning and education but are also highly applicable for lifetime learning. Moreover, self-directed learning promotes lifelong effects of positive attributes towards learning experiences such as becoming more disciplined, attentive, responsible, and creative in planning one's learning objectives.

\section{Acknowledgement}

This work was supported by Universiti Kebangsaan Malaysia [GPK-P\&P-2020-007] and [GGPM-2018-072].

\section{About the Authors:}

Dr. Nor Hafizah Adnan is a senior lecturer of Educational Technology at the Faculty of Education, Universiti Kebangsaan Malaysia (UKM). Her areas of concentration are design and development of technology-enhanced learning environments, augmented reality in education, and teaching practices in a technology-oriented curriculum. ORCID: https://orcid.org/00000001-9368-7646 
Siti Shakirah Sayadi received a bachelor's degree in Education (Teaching English as a Second Language) from Universiti Kebangsaan Malaysia. Her research interests include self-directed learning, language learning strategies, as well as language pedagogy and the use of technology in teaching English as Second Language.

\section{References}

Adnan, N. H. (2018). An interactive mobile augmented reality textbook for learning biology. Journal of Advanced Research in Dynamical and Control Systems, 10, 17191725.

Adnan, N. H., Norman, H. \& Nordin, N. M. (2020). Instructor-generated hand-drawn 2D animations for ESL vocabulary learning in secondary education. The Asian ESP Journal 16(1.2): 67-81.

Adnan, N.H., Ritzhaupt, A.D. (2018). Software Engineering Design Principles Applied to Instructional Design: What can we Learn from our Sister Discipline?. TechTrends 62, 77-94.

Ally, M. (2004). Foundations of educational theory for online learning. In Terry (Ed.), The theory and practice of online learning (pp. 3-31). (2nd ed). Athabasca, AB: Athabasca University.

Ansarimoghaddam, S. \& Tan, B. H. (2014). Undergraduates' experiences and attitudes of writing in L1 and English. GEMA Online Journal of Language Studies.

Asfar, N., \& Zainuddin, Z. (2015). Secondary students' perceptions of information, communication and technology (ICT) use in promoting self-directed learning in Malaysia. The Online Journal of Distance Education and E-Learning, 3(4), 67-82.

Bakar, M. A. A., Fauzi, N. S. M., Badaruddin, S. B., Misiran, M., \& Yusof, Z. M. Malaysia Projection for the Developed Nation Status. Population, 25(150), 2020.

Bandura, A. (1977). Self-efficacy: Toward a unifying theory of behavioral change. Psychological Review, 84, 191-215.

Bandura, A. (2001). Social Cognitive : An Agentic Perspective. Annual Review of Psychology.

Benson, P. (2007). Autonomy in language teaching and learning. Language Teaching.

Benson, P. (2011). What's new in autonomy. The Language Teacher.

Blachowicz, C., \& Ogle, D. (2017). Reading comprehension: Strategies for independent learners. Guilford Publications.

Boyer, S. L., Edmondson, D. R., Artis, A. B., \& Fleming, D. (2014). Self-directed learning: A tool for lifelong learning. Journal of Marketing Education, 36(1), 20-32.

Clark, J. T. (2020). Distance education. In Clinical engineering handbook (pp. 410-415). Academic Press.

Ellis, R. (2004). Down with boring e-learning! Interview with e-learning guru Dr. Michael W. Allen. Learning circuits.

Flower, L., \& Hayes, J. R. (1980). The cognition of discovery: Defining a rhetorical problem. College composition and communication, 31(1), 21-32.

Gardner, R. C., \& Lambert, W. E. (1972). Attitudes and motivation in second language learning (Vol. 786). Newbury: Rowley.

Hashim, H., Yunus, M.M., \& Zakaria, N.Y.K. (2020). Pre-University ESL Learners' Attitude towards M-Learning: An Investigation on the Moderating Role of Gender. Asian EFL Journal, 27(43), 40-64.

Hennessey, B., Moran, S., Altringer, B., \& Amabile, T. M. (2015). Extrinsic and intrinsic 
motivation. Wiley encyclopedia of management, 1-4.

Hiltz, S. R., \& Turoff, M. (2005). Education goes digital: The evolution of online learning and the revolution in higher education. Communications of the ACM, 48(10), 59-64.

Huang, H. M. (2002). Toward constructivism for adult learners in online learning environments. British Journal of Educational Technology, 33(1), 27-37.

Hyland, K. (2018). Metadiscourse: Exploring Interaction in Writing. Bloomsbury Publishing. Ibrahim, I. S., \& Adnan, N. H. (2020). Students Teams-Achievement Division (STAD) for Enhancing Speaking Performance and Teamwork Satisfaction in English as a Second Language (ESL) Classrooms. Akademika, 90(3), 19-28.

Ibrahim, M. M., Arshad, M. Y., Rosli, M. S., \& Shukor, N. A. (2017). The roles of teacher and students in self-directed learning process through blended problem-based learning. Sains Humanika, 9(1-4).

Kaufman, K. J. (2013). 21 ways to 21 st century skills: why students need them and ideas for practical implementation. Kappa Delta Pi Record, 49(2), 78-83.

King, F. B., Young, M. F., Drivere-Richmond, K., \& Schrader, P. G. (2001). Defining distance learning and distance education. AACE journal, 9(1), 1-14.

Knowles, M. S. (1975). Self-directed learning: A guide for learners and teachers.

Littlewood, W. (1996). "Autonomy": An anatomy and a framework. System.

Lounsbury, J. W., Levy, J. J., Park, S. H., Gibson, L. W. \& Smith, R. (2009). An investigation of the construct validity of the personality trait of self-directed learning. Learning and Individual Differences.

Ministry of Education, Malaysia. (2013). Malaysia Education Blue-print 2013: Preliminary Report 2013-2025.

Moore, M. G., \& Kearsley, G. (2011). Distance education: A systems view of online learning. Cengage Learning.

Nunan, D. (1996). Designing and Adapting Materials to Encourage Learner Autonomy. Autonomy and Independence in Language Learning.

Oblinger, D., \& Oblinger, J. (2005). Is it age or IT: First steps toward understanding the Net generation. Educating the Net generation, 2(1-2), 20.

Peen, T. Y., \& Arshad, M. Y. (2017). Collaborative and self-directed learning processes: A case study in Chemistry PBL lesson. IJER-Indonesian Journal of Educational Review, 4(1), 113.

Pintrich, P. R. \& De Groot, E. V. (1990). Motivational and Self-Regulated Learning Components of Classroom Academic Performance. Journal of Educational Psychology.

Razali, N. (2017). ESL in Malaysia: Looking beyond the classroom. The English Teacher, 11. Saadiyah, D. \& Subramaniam, K. (2009). Error Analysis of the Written English Essays of Secondary School Students in Malaysia : A Case Study. European Journal of Social Sciences.

Schunk, D. H. 2005. Self-regulated learning: The educational legacy of Paul R. Pintrich. Educational Psychologist.

Spolsky, B. (1969). Attitudinal aspects of second language learning. Language learning, 19(3-4), 271-275.

Tavangarian, D., Leypold, M. E., Nölting, K., Röser, M., \& Voigt, D. (2004). Is e-Learning the Solution for Individual Learning?. Electronic Journal of E-learning, 2(2), 273-280.

Triacca, L., Bolchini, D., Botturi, L., \& Inversini, A. (2004). Mile: Systematic usability evaluation for e-Learning web applications. In EdMedia+ Innovate Learning (pp. 43984405). Association for the Advancement of Computing in Education (AACE). 
Wan, C. W. I. R. C., Prain, V., \& Collet, P. (2014). Perceived learning strategies of Malaysian university students in Web 2.0-based English as a second language informal learning. GEMA Online ${ }^{\circledR}$ Journal of Language Studies, 14(1).

Williamson, S. N. (2007). Development of a self-rating scale of self-directed learning. Nurse researcher, $14(2)$.

$\mathrm{Wu}, \mathrm{Y}$. L. (2008). Language learning strategies used by students at different proficiency levels. Asian EFL Journal, 10(4), 75-95.

Zimmerman, B. J. (2002). Becoming a Self-Regulated Learner: An Overview. Theory Into Practice.

Zheng, Y., \& Yu, S. (2019). What has been assessed in writing and how? Empirical evidence from Assessing Writing (2000-2018). Assessing Writing, 42, 100421. 